\title{
Gümrük Suç ve Kabahatlerinde Pişmanlık: Karşılaştırmalı Bir Değerlendirme
}

\section{Repentance in Customs Crimes and Misdemeanors: A Comparative Assessment}

\begin{tabular}{l|r} 
Metin $\operatorname{Taş}^{*}$ & RESEARCH \\
ARTICLE
\end{tabular}

\section{ARTICLE INFO}

Submitted : 14.04.2021

Revised : 28.05.2021

Accepted : 02.06.2021

Available : 30.06.2021

iThenticate similarity

score: $7 \%$

JEL classification:

$\mathrm{H} 2 \mathrm{O}, \mathrm{H} 21, \mathrm{H} 26, \mathrm{H} 29$

Keywords:

Tax, Repertance,

Custom, Customs

Misdemeanors,

Customs Smuggling

\begin{abstract}
A B S T R A C T
Repentance provides an opportunity for those who have acted against the law. Thanks to repentance, people who have acted against the law, but who apply before the administration takes action, will be largely freed from penalties. As a result, the administration does not encounter excessive or unnecessary workload.

Provisions that can also be expressed as "effective repentance" in customs duties are regulated separately in Customs Law No. 4458 in terms of misdemeanors and in the Anti-Smuggling Law No. 5607 in terms of crimes.

There are some uncertainties about the repentance institution in customs duties. These uncertainties hinder the effectiveness of the regulation. The aim of this study is to evaluate the regret establishment in taxes and customs duties within the scope of Tax Procedure Law comparatively. As a result of the study, it has been determined that the said repentance provisions have different qualities in many respects.
\end{abstract}

Cite this article as: Taş, M. (2021). "Gümrük Suç ve Kabahatlerinde Pişmanlık: Karşılaştırmalı Bir Değerlendirme", International Journal of Public Finance, 6(1), 63-78.

\begin{tabular}{ll}
\multicolumn{2}{l}{ MAKALE Bígisi } \\
\hline Gönderme: & 14.04 .2021 \\
Düzeltme & $: 28.05 .2021$ \\
Kabul $\quad: 02.06 .2021$ \\
Yayın $\quad: 30.06 .2021$ \\
\hline
\end{tabular}

Ö Z

Pişmanlık, kanuna aykırı davranışlarda bulunanlara bir fırsat sunmaktadır. Pişmanlık sayesinde kanuna aykırı davranışta bulunmuş, ancak bununla ilgili idare harekete geçmeden önce başvuruda bulunan kişiler cezalardan

\footnotetext{
* Prof. PhD., İstanbul Gedik University, Department of Political Science and Public Administration, Turkey, ORCID: 0000-0001-5007-7418,ymmmetintas@gmail.com
} 
Taş, M. (2021). “Gümrük Suç ve Kabahatlerinde Pişmanlık: Karşılaştırmalı Bir Değerlendirme”, International Journal of Public Finance, 6(1), 63-78.

iThenticate benzerlik oranı: $\% 7$

JEL Kodu:

$\mathrm{K} 34, \mathrm{H} 2 \mathrm{O}, \mathrm{H} 29$

Anahtar Kelimeler:

Vergi, Pişmanlık,

Gümrük, Gümrük

Kabahatleri, Gümrük

Kaçakçılığı önemli ölçüde kurtulmuş olurlar. Bunun sonucunda idare de fazla veya gereksiz iş yükü ile karşılaşmamış olmaktadır.

Vergileme alanında "pişmanlık ve ıslah" müessesesi 213 sayılı Vergi Usul Kanununda düzenlenmiş iken, gümrük vergilerinde "etkin pişmanlık" olarak da ifade edilebilecek hükümler kabahatler bakımından 4458 sayılı Gümrük Kanununda, suçlar bakımından ise 5607 sayılı Kaçakçılıkla Mücadele Kanununda ayrı ayrı düzenlenmiştir.

Gümrük vergilerindeki pişmanlık müessesesinde bazı belirsizlikler bulunmaktadır. Bu belirsizlikler düzenlemenin etkinliğine engel olmaktadır. Bu çalışmanın amacı, Vergi Usul Kanunu kapsamındaki vergilerde ve gümrük vergilerinde pişmanlık müessesesinin karşılaştırmalı olarak değerlendirmektir. Çalışmanın sonucunda söz konusu pişmanlık hükümlerinde birçok açıdan birbirinden farklı niteliklere sahip olduğu tespit edilmiştir.

\section{Giriş}

Toplumsal yaşam, huzurlu ve güvenli bir ortamı gerekli kılmaktadır. Bunu sağlamak amacıyla oluşturulan düzen, düzeni koruyucu kuralların ihlaliyle bozulursa, yeniden kurulması için yaptırım uygulanması gerekir (Centel, 2001: 370).

Kural ihlaline karşı uygulanan yaptırımların temel amacı, kurallara aykırı davranışların önlenmesidir. Yaptırımlar diğer yandan da ilgililerin "ıslah" edilmesini amaçlamaktadır.

Hukuka aykırı fiillerin tamamının kamu otoritesi tarafından tespiti ve yaptırıma bağlanması mümkün bulunmamaktadır. Böyle bir durumda, tespit edilemeyen ya da tespiti zor olan hukuka aykırı fiiller için ilgililere bazı çıkış kapıları da aralanmıştır (Bayraklı, 2017: 47).

Bunlardan birisi olan "pişmanlık" birçok hukuk dalında uygulanmaktadır. Belirtmek gerekir ki, aralarında benzerlikler olmasına rağmen Vergi Usul Kanunu (VUK) kapsamında yer alan pişmanlık ile etkin pişmanlık birbirinden farklıdır.

Etkin pişmanlık; "kanunda gösterilen bazı suçların tamamlanmasından sonra, failin fiilinden pişmanlık duyması ve belli bir muhakeme aşamasına kadar, bu suçun olumsuz etkilerini gidermesi ya da suça son vermesi hâlinde, cezasını azaltan ya da kaldıran şahsi bir sebeptir" (Baba, 2011: 141). Vergi Usul Kanununda düzenlenmiş olan pişmanlık ise etkin pişmanlıktan farklı, vergi hukuku alanına özgü bir yapıdadır.

Pişmanlık konusunda, hem VUK kapsamındaki vergilerde hem de gümrük vergilerinde düzenlemeler bulunmaktadır. Vergilemenin bu iki farklı alanındaki pişmanlık hem kapsam hem de uygulanma şekli olarak birbirinden oldukça farklıdır.

Gümrük suç ve kabahatlerinde pişmanlık konusunda yeterince "karşılaştırmalı" akademik çalışma bulunmaması, bizi böyle bir çalışma yapmaya itmiştir. Bu çalışmada, gümrük vergilerinde uygulanan pişmanlık ile VUK'da düzenlenen pişmanlık hükümleri karşılaştırmalı olarak ele alınarak konu hakkındaki görüş ve önerilere yer verilecektir. 
Taş, M. (2021). “Gümrük Suç ve Kabahatlerinde Pişmanlık: Karşılaştırmalı Bir Değerlendirme”, International Journal of Public Finance, 6(1), 63-78.

\section{Vergi Usul Kanunu Kapsamındaki Vergilerde Pişmanlık}

VUK kapsamında düzenlenen pişmanlık tamamen kendine özgü bir nitelik arz etmektedir. VUK'ta düzenlenen pişmanlık; etkin pişmanlık, gönüllü vazgeçme ve ön ödeme ile benzeyen yönlerine karşın sui jeneris bir düzenlemedir.

VUK'ta düzenlenen "pişmanlık ve ıslah" müessesesi, beyana dayanan vergilerde vergi ziyaı cezası kesilmesini gerektiren fiilleri işleyenleri ve bu fiillere iştirak edenleri kapsamaktadır. Bu durumdakilerin kanuna aykırı eylemlerini kendiliğinden ilgili makamlara bildirmeleri ve VUK'un 371. maddesinde belirlenmiş şartları yerine getirmeleri gerekmektedir. Bu şartlar şu şekilde belirtilebilir:

"- Mükellefin (veya iştirakçinin) durumu haber verdiği tarihten önce bir muhbir tarafindan herhangi resmi bir makama haber verilen konu hakkında ihbarda bulunulmamış olması,

- Haber verme dilekçesinin yetkili memurlar tarafından mükellef nezdinde herhangi bir vergi incelemesine başlandığı veya olayın takdir komisyonuna intikal ettirildiği günden önce verilmiş ve resmi kayıtlara geçirilmiş olması,

- Hiç verilmemiş olan vergi beyannamelerinin mükellefin haber verme dilekçesinin verildiği tarihten başlayarak onbeş gün içinde tevdi olunması,

- Eksik veya yanlış yapılan vergi beyanının mükellefin durumu keyfiyeti haber verme tarihinden başlayarak onbeş gün içinde tamamlanması veya düzeltilmesi,

- Mükellefçe haber verilen ve ödeme süresi geçmiş bulunan vergilerin, ödemenin geciktiği her ay ve kesri için, AATUHK hükümlerine göre uygulanacak gecikme zammı oranında bir zamla birlikte haber verme tarihinden başlayarak onbeş gün içinde ödenmesi."

Pişmanlık şartlarına bakıldığında, başvuru sonrasında eylemli bazı sonuçların ortaya çıkmasının arandığı görülmektedir. Yasada belirlenen şartları eksiksiz olarak yerine getirenlerin müesseseden yararlanması konusunda idarenin takdir yetkisi bulunmamaktadır (Şenyüz, 2017: 288).

VUK'ta düzenlenen pişmanlık müessesesi vergi kabahatlerinden sadece vergi ziyaı cezası kesilmesini gerektiren fiilleri kapsamaktadır. Usulsüzlük ve özel usulsüzlük cezası kesilmesini gerektiren fiiller pişmanlık kapsamı dışındadır.

Vergi suçları bakımından pişmanlık VUK'un 359/4. maddesi hükmüne dayalı olarak kaçakçılık fiillerini kapsamaktadır. Ancak VUK'un 371. maddede yer alan; "Beyana dayanan vergilerde vergi ziyaı cezasını gerektiren fiilleri işleyen ..." ifadesi nedeniyle, sadece vergi ziyaının ortaya çıktığı kaçakçılık fillerinin kapsamda olduğu yönünde görüşler bulunmaktadır. Şüphesiz aksi yönde görüşler ve yargı kararları da bulunmaktadır (Bkz. Bozdoğanoğlu, 2016: 158-161). Söz konusu görüşler çalışmamızın kapsamı dışında olduğundan üzerinde durulmayacaktır. 


\section{Gümrük Kabahatlerinde Pişmanlık}

Gümrük kabahatlerinde pişmanlık hükümleri vergi cezasını gerektiren "bazı fiiller" için uygulanmaktadır. Düzenleme Gümrük Kanununun 234. maddesinin üçüncü fıkrasında ve 235. maddesinin altıncı fıkralarında yer almaktadır. Bunların dışında, Gümrük Kanununun 63 ve 64. maddelerindeki hükümler üzerinde de durulmasında yarar bulunmaktadır. Aşağıda bu hükümlere değinilecektir.

\subsection{Gümrük Kanununun 234. Maddesinde Yer Alan Düzenleme}

Gümrük Kanununun 234. maddesinde yer alan düzenlemeyle maddenin ilk iki fıkrasında sayılan fiiller için pişmanlık uygulaması söz konusudur. Bu fiiller;

"- Serbest dolaşıma giriş rejimi veya kısmi muafiyet suretiyle geçici ithalat rejimine tabi tutulan eşyaya ilişkin olarak, yapılan beyan ile muayene ve denetleme veya teslimden sonra kontrol sonucunda;

15 inci maddede belirtilen Gümrük Tarifesini oluşturan unsurlarda veya vergilendirmeye esas olan sayı, baş, ağırlık gibi ölçülerinde aykırılık görüldüğü ve beyana göre hesaplanan ithalat vergileri ile muayene sonuçlarına göre alınması gereken ithalat vergileri arasındaki fark \%5'i aştığı takdirde, ithalat vergilerinden ayrı olarak bu farkın üç katı para cezası alınır.

Kıymeti üzerinden ithalat vergilerine tabi eşyanın beyan edilen kıymeti, 23 ila 31 inci maddelerde yer alan hükümler çerçevesinde belirlenen klymete göre noksan bulunduğu takdirde, bu noksanlığa ait ithalat vergilerinden başka vergi farkının üç katı para cezası alınır.

Satış birimine göre miktar itibarıyla \%5'i geçmeyen bir fark ile maddi hesap hatasından doğan noksan kıymet beyanlarında, bu farklara ait ithalat vergilerinden başka vergi farkının yarısı tutarında para cezası alınır.

- Dahilde işleme rejimi, gümrük kontrolü altında işleme rejimi ve tam muafiyet suretiyle geçici ithalat rejimi hükümlerine tabi eşyaya ilişkin olarak yapılan beyan ile muayene ve denetleme veya teslimden sonra kontrol sonucunda; birinci fikrada belirtilen farklılıkların tespiti durumunda vergi farkının yarısı tutarında idari para cezası verilir."

Yukarıda yer alan ve iki fıkra halinde belirtilen fiiller ile ilgili pişmanlık düzenlemesine Gümrük Kanununun 234. maddesinin üçüncü fıkrasında şu şekilde yer verilmiştir:

"Yukarıda belirtilen aykırılıkların gümrük idaresince tespit edilmesinden önce beyan sahibince bildirilmesi durumunda söz konusu cezalar yüzde on nisbetinde uygulanır."

Etkin pişmanlık hali olarak değerlendirilebilecek olan (Aksüt, Gök. 2016: 77) bu düzenlemeden görüleceği üzere pişmanlık yoluyla, cezaların tamamından vazgeçilmesi 
söz konusu olmayıp bunların yüzde 90’ı kalkmaktadır. Bu hükme göre netice itibariyle belirli bir miktar para cezası halen mevcut olduğundan, pişmanlık beyanında bulunulması uyuşmazlığı sona erdirmemektedir. Ceza muhatabının düzenlenecek idari para cezasına karşı itiraz, uzlaşma veya Kabahatler Kanununun 17. maddesi anlamında cezalarda indirim yoluna başvuru hakkı halen mevcuttur (Gerçek, 2020: 334).

Cezaların önemli bir bölümünün kalkmasına rağmen, bu konuda bir alt sınır da belirlenmiştir. Bu alt sınır Gümrük Kanununun 234. maddenin 6. fıkrasında yer almaktadır. Buna göre;

"Bir ila üçüncü fıkralara göre verilen cezalar 241 inci maddenin birinci fıkrasında belirtilen miktardan az olamaz." Söz konusu miktar yasa metninde 60 TL olarak yer almaktadır. Yeniden değerleme oranına göre artırılan bu miktar 17.12.2020 tarih ve 31337 sayılı Resmi Gazetede yayımlanan 169 Seri numaralı Gümrük Genel Tebliği ile 2021 yıl için 173 TL olarak belirlenmiştir.

Gümrük Kanununun 234. maddenin beşinci fıkrasında cezanın hiç uygulanmayacağı bir durum da düzenlenmiştir. Şartlı muafiyete tabi dahilde işleme rejiminde doğan telafi edici verginin tam ve zamanında ödenmemesinden kaynaklanan vergi kaybı niteliğinde bir gümrük kabahatine yer verilmiştir. Buna göre verginin ödenmediğinin gümrük idaresince tespitinden önce yükümlüsünce bildirilmesi halinde kabahatten dolayı idari yaptırım uygulanmaz (Gültekin, 2019: 249).

\subsection{Gümrük Kanununun 235. Maddesinde Yer Alan Düzenleme}

Gümrük Kanununun 235. maddesinde idari para cezasını gerektiren fiiller beş fıkra halinde sayılmış olup pişmanlık sadece ilk iki fıkrada yer alan fiiller için söz konusudur. Pişmanlık uygulanacak fiiller aşağıda yer almaktadır:

"1. Serbest dolaşıma giriş rejimine tabi tutulan eşyaya ilişkin olarak, yapılan beyan ile muayene ve denetleme veya teslimden sonra kontrol sonucunda;

a) Eşyanın genel düzenleyici idari işlemlerle ithalinin yasaklanmış olduğunun tespiti hâlinde, varsa eşyanın fark gümrük vergilerinin alınmasının yanı sıra, gümrüklenmiş değerinin dört katı idari para cezası verilir.

b) (a) bendindeki eşyanın değersiz, artık veya atık madde olması durumunda, idari para cezası; dökme halinde gelen eşya için ton başına otuz bin Türk Lirası, ambalajı gelmesi halinde kap başına altı yüz Türk Lirası olarak hesaplanır ve eşya yurtdışı edilir.

c) Eşyanın ithali, belli kuruluşların vereceği ve gümrük idaresine ibrazı veya beyanı zorunlu olan lisans, izin, uygunluk belgesi veya bu belgeler yerine geçen bilgiye bağlı olmasına rağmen, eşya belge veya bilgiye tabi değilmiş ya da belge veya bilgi alınmış gibi beyanda bulunulduğunun tespit 
Taş, M. (2021). “Gümrük Suç ve Kabahatlerinde Pişmanlık: Karşılaştırmalı Bir Değerlendirme”, International Journal of Public Finance, 6(1), 63-78.

edilmesi hâlinde, varsa eşyanın fark gümrük vergilerinin alınmasının yanı sıra, gümrüklenmiş değerinin iki katı idari para cezası verilir.

d) (c) bendindeki eşyanın değersiz, artık veya atık madde olması durumunda, idari para cezası; dökme halinde gelen eşya için ton başına sekiz bin Türk Lirası, ambalajlı gelmesi halinde kap başına iki yüz Türk Lirası olarak hesaplanır ve eşya yurtdışı edilir.

e) Bakanlıkça belirlenecek süre içerisinde, (c) bendinde belirtilen eşyanın ithalinin uygun bulunduğuna ilişkin belge veya bilginin düzenlenmesi veya ilgili kurum veya kuruluş tarafından gerçekleştirilen denetimin olumlu sonuçlandığının bildirilmesi hâlinde, 241 inci maddenin birinci fıkrası uyarınca idari para cezası verilir.

2. Ihracat rejimine tabi tutulan eşyaya ilişkin olarak, yapılan beyan ile muayene ve denetleme veya kontrol sonucunda;

a) Eşyanın genel düzenleyici idari işlemlerle ihracının yasaklanmış olduğunun tespiti halinde, eşyanın gümrüklenmiş değerinin iki katı idari para cezası verilir.

b) Eşyanın ihracı, belli kuruluşların vereceği ve gümrük idaresine ibrazı veya beyanı zorunlu olan lisans, izin, uygunluk belgesi veya bu belgeler yerine geçen bilgiye bağlı olmasına rağmen, eşya belge veya bilgiye tabi değilmiş ya da belge veya bilgi alınmış gibi beyanda bulunulduğunun tespit edilmesi hâlinde, gümrüklenmiş değerinin onda biri kadar idari para cezası verilir.

c) Bakanlıkça belirlenecek süre içerisinde, (b) bendinde belirtilen eşyanın ihracının uygun bulunduğuna ilişkin belge veya bilginin düzenlenmesi veya ilgili kurum veya kuruluş tarafından gerçekleştirilen denetimin olumlu sonuçlandığının bildirilmesi hâlinde 241 inci maddenin birinci fıkrası uyarınca idari para cezası verilir."

Pişmanlık ile ilgili düzenleme Gümrük Kanununun 235. maddenin 6. fıkrasında şu şekilde yer almaktadır: "Birinci ve ikinci fıkralarda belirtilen aykırılıkların gümrük idaresi tarafından tespit edilmesinden önce beyan sahibi tarafından bildirilmesi durumunda bu fıkralara göre hesaplanan cezalar yüzde on oranında uygulanır."

Bu maddede düzenlenen pişmanlık hükümlerinde de belirlenmiş cezanın yüzde 90'ından vazgeçilmektedir. Gümrük Kanununun 234. maddesinde yer alan düzenlemeden farklı olarak; Kanunun 235. maddesine göre pişmanlık uygulamasında verilecek para cezası için bir alt sınır bulunmamaktadır.

\subsection{Gümrük Kanununun 63. ve 64. Madde Hükümleri}

Gümrük Kanununun 63. maddesi; “... başka bir eşyanın beyanı sonucunu doğurmaması kaydıyla, beyan sahibinin talebi üzerine beyannamede yer alan bir veya daha fazla bilginin düzeltilmesine" olanak vermektedir. Bu düzeltme; 
Taş, M. (2021). “Gümrük Suç ve Kabahatlerinde Pişmanlık: Karşılaştırmalı Bir Değerlendirme”, International Journal of Public Finance, 6(1), 63-78.

- Beyan sahibine eşyanın muayene edileceğinin bildirilmesinden,

- Söz konusu bilgilerin yanlış olduğunun tespit edilmesinden,

- Eşyanın teslim edilmesinden önce yapılabilmektedir.

Gümrük Kanununun 64. maddesinde ise rejime ilişkin bir düzeltme olanağı yer almaktadır. Buna göre;

"Gümrük idareleri, beyan sahibinin talebi üzerine ve eşyanın yanlışlıkla beyanname konusu gümrük rejimine tabi tutulmasına veya beyan edildiği rejime tabi tutulmasının özel nedenlerle artık mümkün olmadığına ilişkin kanıtlayıcı belgeleri ibraz etmesi halinde, tescil edilmiş bir beyannameyi iptal ederek, gerektiğinde yeni bir rejim beyanında bulunulmasına izin verebilirler."

Söz konusu maddeler kapsamında gerçekleştirilen "düzeltme" işlemleriyle ilgili açıklamalar Gümrük Yönetmeliğinin 121. maddesinde yapılmıştır. Buna göre eşyanın muayenesi için bilgisayar sistemi tarafından beyanın kontrolü türünün kırmızı hat olarak belirlenmesinden önce yapılan düzeltme talepleri için ceza uygulanmamaktadır. Beyan kontrol türü kırmızı hat olarak belirlenen düzeltme talepleri ise Gümrük Kanunu 234/3 hükümlerine göre cezanın yüzde 10'u uygulanmaktadır.

Yukarıda "düzeltme" olarak yer verilen hükümler de aslında pişmanlık kapsamında değerlendirilebilir. Ancak önceki başlıklarda belirtilen fiiller, "tamamlanmış" işlemleri ifade etmektedir. Buna karşılık "düzeltme" olarak yer verilen hükümler daha çok "bir suçun icra hareketlerine başlayan failin, bu icra hareketlerini tamamlamaktan vazgeçmesi ya da icra hareketlerini tamamlasa bile neticenin gerçekleşmesini önlemesi ve bu nedenle icrasına başladığı suçtan dolayı ceza almaması olarak tanımlanabilecek olan" (Akdağ, 2013:91) gönüllü vazgeçmeye benzemektedir.

\section{Gümrük Suçlarında Pişmanlık}

Gümrük kaçakçılığı kapsamındaki fiiller ve verilecek cezalar 5607 sayılı Kaçakçılıkla Mücadele Kanununun (KMK) 3. maddesinde düzenlenmiştir. "Kaçakçılık Suçları" başııkı bu maddede, suç fiilleri 22 fıkra halinde sayılmıştır. Örneğin birinci fıkrada şu hüküm yer almaktadır:

"Eşyayı, gümrük işlemlerine tabi tutmaksızın ülkeye sokan kişi, bir yıldan beş yıla kadar hapis ve on bin güne kadar adî para cezası ile cezalandırılır. Eşyanın, gümrük kapıları dışından ülkeye sokulması halinde, verilecek ceza üçte birinden yarısına kadar artırılır."

Gümrük işlemlerine tabi tutmaksızın ülkeye eşya sokma fiili farklı şekillerde gerçekleştirilebilmektedir (Bkz. Aktaş, 2015: 111-156). Örneğin, kara sınırlarımızın gümrük kapısı olmayan herhangi bir yerinden ya da gümrük işlemleri yapılmayan bir havaalanı ya da iskele veya sahilden eşyanın yurda sokulması halinde belirtilen suç oluşacaktır (Çıldır \& Şentürk, 2015: 87). 
Taş, M. (2021). “Gümrük Suç ve Kabahatlerinde Pişmanlık: Karşılaştırmalı Bir Değerlendirme”, International Journal of Public Finance, 6(1), 63-78.

KMK'nın 4. maddesinde suçun nitelikli halleri sayılmış olup pişmanlıkla ilgili düzenleme "etkin pişmanlık" başıklı 5. maddede yer almaktadır.

KMK'da yer alan pişmanlık düzenlemesi duruma göre farklı şekillerde uygulanmaktadır. Bu nedenle düzenlemeyi ayrı başlıklar altında incelemekte yarar bulunmaktadır.

\subsection{Cezanın Tamamının Kalktığı Durum}

Gümrük kaçakçıı̆ı suçunda cezanın tamamen kalktığı duruma KMK'nın 5. maddesinin birinci fıkrasının ilk cümlesinde yer verilmiştir. Anılan düzenlemeye göre;

"3 üncü maddede tanımlanan suçlardan birine iştirak etmiş olan kişi; resmî makamlar tarafından haber alınmadan önce, fiili, diğer failleri ve kaçak eşyanın saklandığı yerleri merciine haber verirse, verilen bilginin, faillerin yakalanmasını veya kaçak eşyanın ele geçirilmesini sağlaması halinde cezalandırılmaz."

Pişmanlık halinde cezanın tamamen kalktığı durum sadece iştirakçiler için söz konusu olup asıl faili kapsamamaktadır. Madde metninde yer alan "iştirak etmiş olan kişi” ifadesinden hareketle kapsamın sadece iştirakçiden ibaret olduğu anlamı çıkmaktadır.

Nitelik olarak bir kişi tarafından işlenebilen bir suçun birden çok kişi tarafından işbirliği içinde işlenmesi halinde suça iştirakten söz edilmektedir (Şenyüz, 2017: 461). İştirak halinde işlenen suçların cezalandırıması konusunda eşitlik ve ikilik olmak üzere iki farklı sistem uygulanmaktadır. Eşitlik sisteminde suçun işlemesine katkısı olan herkes, indirim uygulanmaksızın işlenen suçun cezasıyla cezalandırılmaktadır. Ceza hukukumuzda benimsenen ikilik sisteminde ise suça iştirak edenlerin suça sağlamış oldukları katkılara göre cezalandırılmaları söz konusudur (Özen, 2007: 239).

Bağlıık kuralına göre fail ve suç ortakları ayrı kişilerdir ve fail olan kişi suç ortağı, suç ortağı olan kişi ise fail olamamaktadır (Temiz, 2016: 2489). Suçun kanuni tanımında öngörülen fiili gerçekleştirmeyen, ancak suçun gerçekleşmesi için nedensel değeri bulunan hareketleri icra eden suç ortakları iştirakçi (şerik) olarak kabul edilmektedir. Kanunumuza göre iştirakçilik statüsü "yardım etme" ve "azmettirme" olmak üzere iki türlüdür (Kaymaz, 2012: 120).

Yukarıda yer verilen açıklamalardan anlaşılacağı üzere, pişmanlık halinde cezanın tamamen kaldırılacağı hal sadece iştirakçiler için söz konusu olmaktadır. Bu noktada iştirakin azmettirme veya yardım etme şeklinde olmasının bir önemi bulunmamaktadır.

İştirakçiler için geçerli olan pişmanlık düzenlemesi şarta bağlı bir düzenleme durumundadır. Buna göre iştirakçi tarafından "verilen bilginin, faillerin yakalanmasını veya kaçak eşyanın ele geçirilmesini sağlaması" gerekmektedir. Faillerin yakalanmasının ya da kaçak eşyanın ele geçirilmesinin mümkün olmadığı hallerde şartlar sağlanmamış olacağından, pişmanlık hükümlerinden yararlanılması mümkün olmayacaktır. 


\subsection{Cezanın Kısmen Kalktığı Durumlar}

Cezanın tamamen kalktığı durum sadece iştirakçilere yönelik olmasına rağmen, cezanın kısmen kalktığı durumlar iştirakçiler de dahil bütün suç işleyenleri kapsamına almaktadır. Cezanın kısmen kalktığı iki durum söz konusudur.

\subsubsection{Suçun Ortaya Çıkmasına Yardım Edilmesi Halinde}

Suçun ortaya çıkmasına yardım edilmesi halinde cezanın kısmen veya tamamen kalktığı duruma KMK'nın 5. maddesinin birinci fıkrasının ikinci cümlesinde yer verilmiştir. Anılan düzenlemeye göre;

"Haber alındıktan sonra fiilin bütünüyle ortaya çıkmasına hizmet ve yardım eden kişiye verilecek ceza üçte iki oranında indirilir."

Maddede yer alan düzenlemede herhangi bir belirleme yapılmadığından maddenin ilk cümlesindeki düzenlemeden farklı olarak, hem faili hem de iştirakçileri kapsamaktadır. İki durum arasındaki diğer farklılık ise suçtan resmi makamların haberi olup olmaması konusundadır.

Maddenin ilk fıkrasındaki düzenleme resmi makamların suçtan haberi olmadığı bir durumla ilgilidir. İkinci cümledeki düzenleme ise resmi makamların suçtan haberinin olduğu ancak henüz bütünüyle ortaya çıkarılamadığı bir durumla ilgilidir.

\subsubsection{Zararın Giderilmesi Halinde}

Zararın giderilmesi halinde etkin pişmanlık ile ilgili düzenleme 14.04.2020 tarih ve 7247 sayılı Kanunla getirilmiştir. Önceki etkin pişmanlık düzenlemesinin uygulamada yarattığı sıkıntılar nedeniyle uzun zamandır beklenen bu değişiklik son derece olumludur (Ümit, 2021: 141). KMK'nın 5. maddesinin ikinci fıkrasında yapılan düzenlemeye göre;

"Yedinci fıkrası hariç, 3 üncü maddede tanımlanan suçlardan birini işlemiş olan kişi, etkin pişmanlık göstererek suç konusu eşyanın gümrüklenmiş değerinin iki katı kadar parayı Devlet Hazinesine;

a) Soruşturma evresi sona erinceye kadar ödediği takdirde, hakkında bu Kanunda tanımlanan kaçakçılık suçlarından dolayı verilecek ceza yarı oranında,

b) Kovuşturma evresinde hüküm verilinceye kadar ödediği takdirde, hakkında bu Kanunda tanımlanan kaçakçılık suçlarından dolayı verilecek ceza üçte bir oranında,

indirilir. Bu husus, soruşturma evresinde Cumhuriyet savcısı tarafından şüpheliye ihtar edilir. Soruşturma evresinde ihtar yapılmaması hâlinde kovuşturma evresinde hâkim tarafından sanığa ihtar yapılır." 
Cezanın kısmen kaldırılması için eşyanın gümrüklenmiş değerinin iki katı ödeme yapılması gerekmektedir. Cezanın kalkma oranları ödemenin yapıldığı hukuksal aşamaya göre farklılık göstermektedir. Ayrıca soruşturma aşamasının yanı sıra kovuşturma aşamasında da ihtar yapılması mümkün kılınmıştır. Buna ilave olarak kaçakçılık suçundan hakkında soruşturma başlatılan kişiye soruşturma aşamasında da etkin pişmanlıktan faydalanma hakkı verilmiştir.

Diğer taraftan zararın giderilmesi halinde cezanın kısmen kaldırıldığı durum yedinci fıkrada yer alan suçlar için söz konusu değildir. Anılan fıkra şu şekildedir:

"ithali kanun gereği yasak olan eşyayı ülkeye sokan kişi, fiil daha ağır bir cezayı gerektiren suç oluşturmadığı takdirde, iki yıldan altı yıla kadar hapis ve yirmi bin güne kadar adî para cezası ile cezalandırılır. Ithali yasak eşyayı, bu özelliğini bilerek satın alan, satışa arz eden, satan, taşıyan veya saklayan kişi, aynı ceza ile cezalandırılır."

Zararın giderilmesi halinde cezanın kısmen kalktığı duruma ilişkin diğer bir kısıtlama KMK'nın 5. maddesinin üçüncü fıkrasında yer almaktadır. Buna göre;

"ikinci fıkra hükmü, mükerrirler hakkında veya suçun bir örgütün faaliyeti çerçevesinde işlenmesi hâlinde uygulanmaz."

5607 sayılı Kaçakçılıkla Mücadele Kanununda "mükerrir" ya da "tekerrür" kavramlarına yer verilmemiştir. Bu nedenle ceza hukuku normlarına başvurmak gerekmektedir. Tekrarlama anlamına gelen tekerrür, daha önceden işlemiş olduğu bir suçtan dolayı kesin bir hükümle mahkûm olmuş bir kimsenin, öngörülen süre geçmeden yeni bir suçu işlemesi halidir. Burada ikinci suçu işleyen şahsa mükerrir denilmektedir (Özbey, 2010: 55).

5237 sayılı Türk Ceza Kanununun 58. maddesine göre;

"Önceden işlenen suçtan dolayı verilen hüküm kesinleştikten sonra yeni bir suçun işlenmesi halinde, tekerrür hükümleri uygulanır. Bunun için cezanın infaz edilmişolması gerekmez.

Tekerrür hükümleri, önceden işlenen suçtan dolayı;

- Beş yıldan fazla süreyle hapis cezasına mahkûmiyet halinde, bu cezanın infaz edildiği tarihten itibaren beş yıl,

- Beş yıl veya daha az süreli hapis ya da adlî para cezasına mahkûmiyet halinde, bu cezanın infaz edildiği tarihten itibaren üç yıl geçtikten sonra işlenen suçlar dolayısıyla uygulanmaz."

Suçun örgüt faaliyeti çerçevesinde işlenmesi halinde de zararın giderilmesi halinde ceza indiriminden yararlanılamamaktadır. Suç işlemek amacıyla örgüt kurma suçu, 5237 sayılı Türk Ceza Kanununun 220. maddesinde düzenlenmiştir. Buna göre, suç işlemek amacıyla kurulan yapılanmanın bazı özellikleri taşıması gerekir. Öncelikle; örgüt, süreklilik gösteren, kendisini oluşturanlar arasında planlı ortaklık, iş bölümü bulunan, başında bir lider olan ve en az üç kişiden oluşan suç işlemek için kurulmuş bir yapılanmadır. Örgüt, bu özellikleri ile rastgele fiili bir birliktelik değil, suç işlemek amacı 
Taş, M. (2021). “Gümrük Suç ve Kabahatlerinde Pişmanlık: Karşılaştırmalı Bir Değerlendirme”, International Journal of Public Finance, 6(1), 63-78.

doğrultusunda dayanışma, organizasyon ve koordinasyonu içeren disiplinli bir yapıdır (Yenidünya \& İçer, 2013: 800).

\section{Pişmanlık Hükümlerinin Karşılaştırılması}

Gümrük kabahat ve suçları ile vergi kabahat ve suçlarına uygulanan pişmanlık hükümleri birçok açıdan birbirinden farklıdır. Söz konusu farklılıklar, suçlar ve kabahatler açısından aşağıda yer alan tablolarda özetlenmiştir.

Tablo 1: Kabahatler Açısından Pişmanlık Hükümlerinin Karşılaştırılması

\begin{tabular}{|c|c|c|}
\hline Karşılaştırma Unsuru & Vergi Usul Kanunu & Gümrük Kanunu \\
\hline Usulsüzlük Cezaları & Kapsam Dışı & Kapsam Dışı \\
\hline Vergi Kaybına Sebep Olan Fiiller & Bütün Fiiller & Kanunda Sayılan Bazı Fiiller \\
\hline \multirow[t]{3}{*}{ Ceza Uygulaması } & \multirow[t]{3}{*}{ Ceza Uygulanmaz } & Ceza Uygulanmaz 234/5 \\
\hline & & \% 90 İndirimli Ceza \\
\hline & & $\begin{array}{l}\text { \% } 90 \text { İndirimli Ceza (Bazı fiiller } \\
\text { için asgari tutar) }\end{array}$ \\
\hline Beyan ve Ödeme Şartı & Var & Yok \\
\hline
\end{tabular}

Yukarıdaki Tablo 1'den da görüldüğü gibi VUK'da ve Gümrük Kanununda düzenlenen pişmanlık hükümleri arasında bazı ortak noktalar bulunmakla birlikte, daha çok farklılıklar bulunmaktadır. Her iki kanundaki hükümlere göre usulsüzlük cezaları pilmanlık müessesesinin kapsamına girmemektedir. Diğer taraftan VUK'daki pişmanlık hükümleri; vergi kaybına sebep olan bütün fiilleri kapsamakta, herhangi bir ceza uygulaması öngörmemekte ve yararlanmak için beyan ve ödeme şartı aranmaktadır.

Buna karşılık Gümrük Kanunundaki pişmanlık hükümleri; vergi kaybına sebep olan sadece bazı fiilleri kapsamakta, bazı durumlarda herhangi bir ceza uygulanmaz iken, bazı durumlarda az da olsa bir ceza kesilmekte ve yararlanmak için beyan ve ödeme şartı bulunmamaktadır.

Tablo 2: Suçlar Açısından Pişmanlık Hükümlerinin Karşılaştırılması

\begin{tabular}{|l|l|l|}
\hline \multicolumn{1}{|c|}{ Karşılaştırma Unsuru } & \multicolumn{1}{c|}{ Vergi Usul Kanunu } & \multicolumn{1}{c|}{$\begin{array}{c}\text { Kaçakçılıkla Mücadele } \\
\text { Kanunu }\end{array}$} \\
\hline Bütün Kaçakçılık Fiilleri & Kapsamda & İstisnası Var \\
\hline Tam Cezasızık & Var & Sadece İştirakçilere \\
\hline İhbar Sonrası İndirim & Yok & Var \\
\hline Ödeme Halinde Ceza İndirimi & Yok & Var \\
\hline Mükerrirler & Kapsamda & Kapsam Dışı \\
\hline Örgütlü Kaçakçılık & Kapsamda & Kapsam Dışı \\
\hline Vergi Kaybı Ölçütü & Tartışmalı & Uygulanmıyor \\
\hline
\end{tabular}


Taş, M. (2021). “Gümrük Suç ve Kabahatlerinde Pişmanlık: Karşılaştırmalı Bir Değerlendirme”, International Journal of Public Finance, 6(1), 63-78.

Tablo 2'de VUK'da ve Kaçakçılıkla Mücadele Kanununda düzenlenen pişmanlık hükümlerinin karşılaştırılmasına yer verilmiştir. Tablodan da görüldüğü gibi pişmanlık hükümleri açısından söz konusu kanun hükümleri arasında büyük farklılıklar bulunmaktadır. VUK'daki pişmanlık hükümleri; bütün kaçakçılık fiillerini kapsamakta, herhangi bir ceza uygulaması öngörmemekte, tekerrür ve örgütlü kaçakçılık halinde de uygulanmakta, ödeme halinde veya ihbar sonrası indirim yapılmamakta ve vergi kaybı ölçütü tartışmalı durumdadır.

Buna karşılık Kaçakçılıkla Mücadele Kanunundaki pişmanlık hükümleri; bazı kaçakçılık fiillerini kapsamakta, sadece iştirakçilere ceza uygulanmamakta, ihbar sonrasında ve ödeme halinde indirim uygulanmakta, ancak mükerrirler, örgütlü kaçakçılık ve vergi kaybı hallerinde ise uygulanmamaktadır.

\section{Uygulamada Karşılaşılan Sorunlar}

Gümrüklerde uygulanan pişmanlık müessesine ilişkin olarak yasa dışındaki kaynaklarda açıklayıcı bir bilgi yer almamaktadır. Kanunun ayrıntılı olmayan dar kapsamlı metni, sübjektif kriterler çerçevesinde değerlendirmeler başta olmak üzere uygulamada birçok sorunu beraberinde getirmektedir. Bu bağlamda, gümrük idaresince konu hakkında "henüz tespit yapılmaması" ifadesinden ne anlaşılması gerektiği bilinememektedir (Yıldız, 2017: 54-55).

Tespit kelimesinin anlamının belirlenmesi, gümrükte pişmanlıkla beyan müessesesinden gerektiği gibi faydalanabilmek açısından son derece önemlidir. Esasında gümrük idareleri tarafından yürütülen denetim faaliyeti sırasında ya da yapılan ihbarlar neticesinde bir kabahatin veya suçun işlendiği tespit edilebilir. Ancak gümrük idareleri arasında "tespit" kavramının yorumlanması ve uygulanması bağlamında farklı anlayışların bulunması uygulamadan beklenen yararların ortaya çıkmasının önünde ciddi bir engel oluşturmaktadır (Uzun, 2018: 100).

Yükümlüler tarafından yapılan pişmanlık başvurularında idare tarafından araştırılması gereken temel husus, yükümlünün bildirdiği hususun gümrük idaresince daha önce tespit edilip edilmediği olmalıdır (Uzun, 2018: 101).

VUK hükümlerinden farklı olarak Gümrük Kanununda pişmanlık halinde idari para cezasının belirli kısmı kaldırılmaktadır. Önceleri cezanın \% 85'i kaldırılırken, 24.10.2019 tarihli ve 7190 sayılı Kanunun 11 inci maddesiyle yapılan değişiklikle kaldırılan oran cezanın \% 90'ı olarak belirlenmiştir. Para cezasının \% 90'ının kaldırılması ile tamamen kaldırılması arasında fazla bir fark yoktur. Kanımızca cezanın tamamının kaldırıması psikolojik olarak olumlu etki bırakacak bir düzenleme olacaktır. Ayrıca Gümrük Kanununun 234 ve 235. maddesinde yer verilen kabahat fiilleri açısından getirilen pişmanlık düzenlemesinin vergi kaybına sebebiyet veren tüm gümrük kabahatleri bakımından uygulanmasının sağlanmasında yarar vardır (Gök, 2019: 283). 
Gümrük kabahatlerinin birden çok kişinin katılımıyla işlenmesi söz konusu olabilir. Bu tür durumlarda kabahate iştirak edenler de sorumluluk altındadır (Kılıç, 2013: 307). Bununla beraber, kabahatlerde pişmanlıktan yararlanma olanağı "beyan sahibi" (ya da adına hareket edenler) için söz konusudur. Beyan sahibi tarafından koşullara uygun olarak pişmanlık başvurusunda bulunulması halinde iştirakçilerin durumu belirsizdir. Bu belirsizliğin giderilmesinin yanında iştirakçiler bakımından da bu yolun açılmasında yarar bulunmaktadır.

Kaçakçılık suçunun işlenmesi halinde pişmanlık yoluna gidilmesinde tam cezasızlık halinin sadece iştirakçiler için öngörülmüş olması önemli bir eksikliktir. İdarece suçun öğrenilmesinden sonra, suçun bütünüyle ortaya çıkmasına hizmet ve yardım eden kişiye uygulanacak ceza indirimi konusunda önemli belirsizlikler mevcuttur. Kanun metninde yer alan "haber alındıktan sonra" ifadesinin anlamının belirlenmesi gerekmektedir. Suçun bütünüyle ortaya çıkmasına "hizmet ve yardım edilmesi" ifadesinde de belirsizlik bulunmaktadır. Söz konusu hizmet ve yardımın ölçüsü nedir? Hizmet ve yardım edildiği ve ne ölçüde edildiği nasıl ispatlanacaktır? Bu hususlar tutanağa mı bağlanacak; yetkililerin beyanına mı itibar edilecek? Bu düzenlemedeki belirsizlik, idareler arası farklı uygulamaların ortaya çıkmasına sebep olma potansiyeli taşımaktadır. Belirlenen bu sorunların çözümü açısından Vergi Usul Kanunu ve ilgili mevzuattaki çözümlemeler dikkate alınarak Gümrük Kanunu ve Kaçakçılıkla Mücadele Kanununda benzer düzenlemeler yapılmalıdır.

Diğer taraftan 7242 sayılı Kanun ile zararın giderilmesi halinde etkin pişmanlık düzenlemesinin değişiklikten önceki halinde etkin pişmanlığın sadece soruşturma aşamasında uygulanmasının Anayasaya aykırılığı gerekçesiyle yapılan iptal başvurusunda AYM, 14.01.2015, E. 2014/127, K. 2015/5 sayılı kararında; "farklı veya benzer suç tipleri için etkin pişmanlığın kapsamının belirlenmesinin ve uygulama alanının daraltılması veya genişletilmesinin kanun koyucunun takdirinde olduğu, bu durumun etkin pişmanlığın özelliği ve bu kurumdan sağlanan hukuki yarar ile ilgili olduğu belirtilerek söz konusu düzenlemenin eşitlik ilkesine aykırı olmadığı gerekçesiyle başvurunun reddine karar verilmiştir". Her ne kadar Anayasa Mahkemesi söz konusu düzenlemenin eşitlik ilkesine aykırı olmadığına karar vermiş ise de, uygulamada yaşanan sorunların devam etmesi, bu kanuni düzenlemenin yapılması ihtiyacını doğurmuştur. Bu nedenle diğer adli cezalarda indirim Türk Ceza Kanunu kapsamında yapılırken, zararın giderilmesi halinde adli cezada indirim sağlanmasına yönelik KMK'da özel hükümlere yer verilmesi de eşitlik ilkesi bakımından sakıncalı olduğunu ifade etmek isteriz. 


\section{Sonuç ve Öneriler}

Hukuka aykırı bütün fiillerin tespit edilmesinin mümkün olmaması nedeniyle, bu konuda çeşitli düzenlemeler yapılması yoluna gidilmiştir. Bunlardan biri olan pişmanlık müessesesi birçok hukuk alanında uygulama olanağı bulmuş durumdadır.

Pişmanlık sayesinde, kamu otoritesince tespiti mümkün olmayan (ya da güç olan) suç ve kabahatlerin belirlenmesi ve ortaya çıkması muhtemel uyuşmazlıkların önüne geçilmesi beklenmektedir. Bu noktadan hareketle, gümrük suç ve kabahatleri için de pişmanlık müessesesi düzenlenmiştir. Ancak bu kanunlarda yer alan düzenlemeler Vergi Usul Kanununda yer alan pişmanlık müessesesine göre oldukça farklı nitelik taşımaktadır.

Diğer taraftan gümrük vergilerinde pişmanlık müessesesine ilişkin yasal düzenlemelerde birçok açıdan belirsizlikler ve bazı eksiklikler bulunmaktadır. Bu belirsizlik ve eksiklikler, müesseseden beklenilen işlevlerin yerine getirilmesine engel olabilecek niteliktedir.

Gümrük suç ve kabahatlerinde pişmanlık düzenlemesinin etkin bir işlev görmesini sağlamak amacıyla öncelikle yasal belirsizliklerin giderilmesi gerekmektedir. Bu bağlamda, Gümrük Kanununun 234 ve 235. maddelerdeki "tespit" sözcüğünün anlamının tartışmaya ve farklı uygulamalara yer bırakmayacak şekilde nesnel olarak belirlenmesi gerekmektedir. Ayrıca bazı gümrük kabahatlerinde uygulanan yüzde 90 oranındaki indirimin yüzde 100 olarak uygulanması ve pişmanlık kapsamına vergi kaybı yaratan bütün fiillerin alınmasında yarar vardır.

Kaçakçılık suçuna ilişkin olarak, KMK'nın 5. maddesinde yer alan "haber alındıktan sonra" ibaresi ile tam olarak neyin ifade edildiği belirlenmelidir. Haber alındıktan sonra, hangi aşamaya kadar yardım ve hizmet talep edileceği, yardım ve hizmetin ne ölçüde olması gerektiği konusundaki belirsizlikler giderilerek, ilgili idarelerin farklı uygulamalarının önüne geçilmelidir.

Gümrük kaçakçılığında tam cezasızlık halinin iştirakçilerin dışında suç failleri için de getirilmesinde yarar vardır. Zira suça ilişkin en fazla ve ayrıntılı bilgi şüphesiz failde mevcuttur. Tam cezasızlık halinin asıl fail için de uygulanabilir olması, uygulamadan yararlanmak isteyen kişi sayısını artırabilecektir.

Son olarak, zararın giderilmesi halinde ceza indirimi sağlanmasına son verilmelidir. Zira işlenen suçlarla ilgili ödeme yapan ve yapmayan bakımından bir ayrımcılık yaratan bu düzenleme eşitlik ilkesi açısından sorunludur. 


\section{Kaynakça}

Akdağ, H. (2013). “Gönüllü Vazgeçme”, Hacettepe Hukuk Fak. Dergisi, 3(2), 91-126.

Aksüt, B. D. \& Gök Ö. (2016). “Gümrük Vergilerinden Kaynaklanan Anlaşmazlıkların Uzlaşma Yolu İle Çözümü”, D.E.Ü. Hukuk Fakültesi Dergisi, 18(2), 75-125.

Aktaş, B. (2015). “Gümrük İşlemlerine Tabi Tutmadan Ülkeye Eşya Sokma Suçu Üzerine Bir İnceleme", TBB Dergisi, 121, 111-156.

Anayasa Mahkemesi, 14.01.2015 tarih ve E. 2014/127, K. 2015/5 sayılı kararı, https://normkararlarbilgibankasi.anayasa.gov.tr/ND/2015/5?EsasNo=2014\%2F 127\&KararAramaRaporu=1\&KararNo=2015\%2F5, (08.05.2021).

Baba, Y. (2011). Türk Ceza Hukukunda Etkin Pişmanlık, (Yayınlanmamış Yüksek Lisans Tezi, İstanbul Üniversitesi Sosyal Bilimler Enstitüsü.

Bayraklı, H. H. (2017). "Pişmanlık ve Islah Hükümleri Karşısında Vergi Kaçakçılık Suçlarının Konumu", Türkiye Adalet Akademisi Dergisi, 31, 47-64.

Bozdoğanoğlu, B. (2016), "Vergi Hukuku ve Ceza Hukuku Normları Açısından Pişmanlık: Sorunlar-Yaklaşımlar-Çözüm Önerileri", International Journal of Public Finance, 1(2), 146-167.

Centel, N. (2001). "Cezanın Amacı ve Belirlenmesi", Prof. Dr. Turhan Tufan Yüce'ye Armağan, Dokuz Eylül Üniversitesi Yayını, 337-372.

Çıldır, Ş. \& Denizhan, H. (2015). Kaçakçılıkla Mücadele Kanunu, 2. Baskı, Yetkin Yayınları Ankara.

Gerçek, A. (2020). Dış Ticaret Işlemleri ve Vergilendirilmesi, Ekin Basım Yayın Dağıtım, Bursa.

Gök, Ö. (2019). Gümrük Vergisinden Kaynaklanan Uyuşmazlıklar, Yetkin Yayınları, Ankara.

Gültekin, R. (2019) Gümrük Kabahatleri: Hukuki Analizi, Sorunlar ve Çözüm Önerileri (Doktora Tezi), Anadolu Üniversitesi Sosyal Bilimler Enstitüsü.

Kaymaz, S. (2012). "5237 Sayılı Türk Ceza Kanuna Göre İştirak Halinde İşlenen Suçlarda Nitelikli Hallerin Diğer Suç Ortaklarına Geçişi Sorunu", Gazi Üniversitesi Hukuk Fakültesi Dergisi, XVI(2), 117-167.

Kılıç, K. (2013) Kaçakçılık Suçları, Gümrük Kabahatleri ve Gümrük Uyuşmazlıklarının Çözüm Yolları, Gazi Kitabevi, Ankara.

Özbey, Ö. (2010). "Suçta Tekerrür ve Mükerrirlere Özgü Güvenlik Tedbirleri", Türkiye Barolar Birliği Dergisi, 88, 55-105.

Özen, M. (2007). “5237 Sayılı Türk Ceza Kanunu’nun İştirak Kurumuna Bakışı”, Türkiye Barolar Birliği Dergisi, 70, 239-253.

Şenyüz, D. (2017). Vergi Ceza Hukuku, 10. Baskı, Ekin Basım Yayın Dağıtım, Bursa. 
Temiz, B. S (2016). "İştirak Hükümleri Açısından Bağlıık Kuralı”, Ankara Üniversitesi Hukuk Fakültesi Dergisi, 65 (4), 2487-2512.

Uzun, F. (2018). “Gümrükte Pişmanlıkla Beyanda Uygulama Sorunları”, Gümrük ve Ticaret Dergisi, 11, 98-101.

Ümit, C. (2021). “Kaçakçılıkla Mücadele Kanununda Etkin Pişmanlık Uygulaması: Yasal Gelişmeler Işığında Analitik Bir İnceleme”, Inönü Üniversitesi Hukuk Fakültesi Dergisi, 12(1), 133-147.

Yenidünya, A. C. \& İçer, Z. (2013). "Suç İşlemek Amacıyla Örgüt Kurma Suçu”, Marmara Üniversitesi Hukuk Fakültesi Hukuk Araştırmaları Dergisi (Prof. Dr. Nur Centel'e Armağan), 19 (2), 797-828.

Yıldız, G. (2017). “Gümrükte Pişmanlık Müessesesi”, Gümrük ve Ticaret Dergisi, 9, 50-56. 